\begin{abstract}
"In adopting our title of the Fournal of Mental Science, published by authority of the Medico-Psychological Association, we profess that we cultivate in our pages mental science of a particular kind, namely, such mental science as appertains to medical men who are engaged in the treatment of the insane. But it has been objected that the term mental science is inapplicable, and that the term mental physiology or mental pathology, or psychology, or psychiatry (a term much affected by our German brethren), would have been more correct and appropriate ; and that, moreover, we do not deal in mental science, which is properly the sphere of the aspiring metaphysical intellect. If mental science is strictly synonymous with metaphysics, these objections are certainly valid; for although we do not eschew metaphysical discussion, the aim of this JoURNAL is certainly bent upon more attainable objects than the pursuit of those recondite inquiries which have occupied the most ambitious intellects from the time of Plato to the present, with so much labour and so little result. But while we admit that metaphysics may be called one department of mental science, we maintain that mental physiology and mental pathology are also mental science under a different aspect. While metaphysics may be called speculative mental science, mental physiology and pathology, with their vast range of inquiry into insanity, education, crime, and all things which tend to preserve mental health, or to produce mental disease, are not less questions of mental science in its practical, that is in its sociological point of view. If it were not unjust to high mathematics to compare it in any way with abstruse metaphysics, it would illustrate our meaning to say that our practical mental science would fairly bear the same relation to the mental science of the metaphysicians as applied mathematics bears to the pure science. In both instances the aim of the pure science is the attainment of abstract truth; its utility, however, frequently going no further than to serve as a gymnasium for the intellect. In both instances the mixed science aims at, and, to a certain extent, attains immediate practical results of the greatest utility to the welfare of mankind; we therefore maintain that our JoURNAL is not inaptly called the Fournal of Mental Science, although the science may only attempt to deal with sociological and medical inquiries, relating either to the preservation of the health of the mind or to the amelioration or cure of its diseases; and although not soaring to the height of abstruse metaphysics, we only aim at such metaphysical knowledge as may be available to our purposes, as the mechanician uses the formularies of mathematics. This is our view of the kind of mental science which physicians engaged in the grave responsibility of caring for the mental health of their fellow-men may, in all modesty, pretend to cultivate; and while we cannot doubt that all additions to our certain knowledge in the speculative department of the science will be great gain, the necessities of duty and of danger must ever compel us to pursue that knowledge which is to be obtained in the practical departments of science with the earnestness of real workmen. The captain of a ship would be none the worse for being well acquainted with the higher branches of astronomical science, but it is the practical part of that science as it is applicable to navigation which he is compelled to study."-Sir F. C. Bucknill M.D., F.R.S.
\end{abstract}




\section{JOURNAL OF MENTAL SCIENCE.}

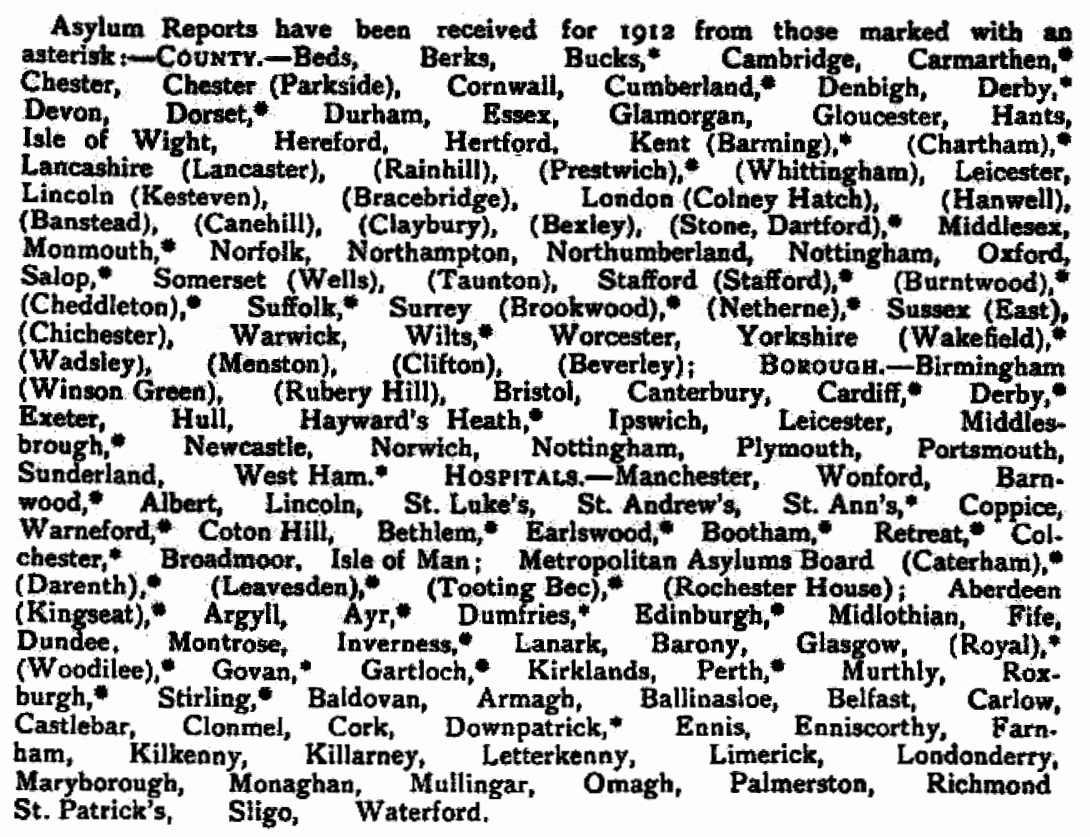

The following Asylum Reports have also come to hand:-Egypt, Cape of Good Hope, Nova Scotia, New Brunswick, Victoria, New York, Massachusetts Hospital, Ontario, Verdun, Warren, Pennsylvania, Phila. delphia Friends, Binghampton, Willard, Northampton, Long View, South Australia, Cleveland, Matteawan, New South Wales, Agra and Oudh, Assam, Madras, Bengal, Bombay, Central Pro-
vinces, Rangoon, Punjab, North-Western Provinces, Tezpur, Mississippi, Pennsylvania Hospital, Washington, Utica, Long Island, Virginia Central, Illinois West, New Hampshire, Butler, Maryland, Pennsylvania West, South Mountain, Manhattan, Indiana East, Con. necticut, Carolina N., Dakota N., Ohio, Carthage, Buffalo, Michigan East, Missouri. Alt Scherbitz, Massachusetts Board, Virginia West, Pennsylvania, Danville, Sheppard and Pratt Hospital, Baltimore, Pennsylvania, Harrisburgs, Pennsylvania, Norristown, Aarhus, Lebanon, Hudson River, Rochester, Taunton, Iowa, Jamaica, Grahamstown, Pretoria, Egypt, Albany, Tarrytown, Straits Settlements, Lower Austria.

Authors of Original Papers receive 25 reprints of their articles free of cost if application be made on the slips when returning proof. If any extra reprints are required, notice should be at the same time sent to the Printers, Messrs. Adrard and Sow, Bartholomew Close, London, E.C., who will supply them at a fixed charge. Uniess instructions are sent by authors of Papers when the proofs are returned, no copies can be guaranteed.

The copies of the Jourmal of Mental Science are regularly sent by carrier, who in every case obtains a receipt of delivery, to the Ordinary and Honorary Members of the Association. Complaints of non-receipt of the Journal should be sent to Messrs. AdLARd. Any change of address should be intimated to the General Secretary. 


\title{
THE DISORDERS
}

\author{
OF
}

\section{POST-NATAL}

GROWTH AND DEVELOPMENT

BY

HASTINGS GILFORD, F.R.C.S.

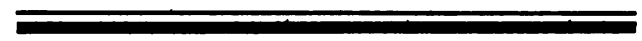

"A great book, wide in its scope, great in its aims, and excellent in its execution."-Professor Keith: 'Man.'

"The book is not only crammed with information, but is most enjoyable to read."-'Medical Review.'

Large Royal 8vo, pp. $727+$ xxii, with 64 Illustrations.

Prioe 158. not.

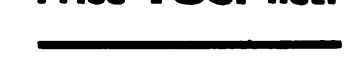

ADLARD \& SON, BARTHOLOMEW GLOSE, E.C. 


\section{Mental or Physical Fatigue}

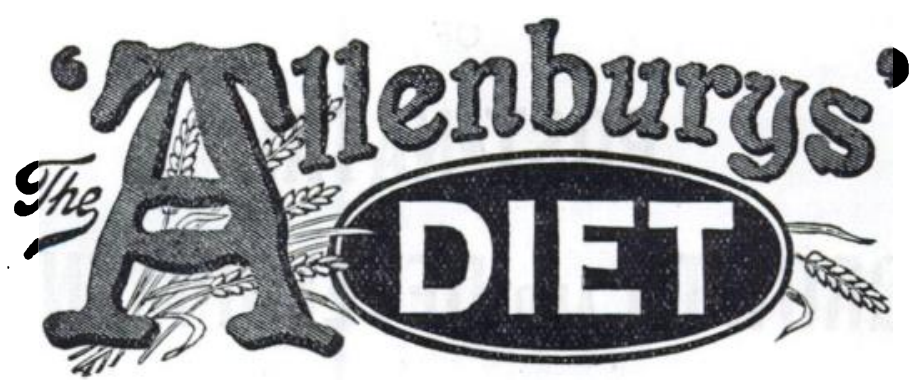

\section{A PARTIALLY PRE-DIGESTED MILK AND WHEATEN FOOD.}

When brain or body is weary the digestive powers are weakened and distaste for ordinary food is often experienced. Under such circumstances the "ALLENBURYS" DIET is especially valuable. It is pleasant to take, easily digested and assimilated, and speedily restorative. Thus it helps the system to recover tone and vigour.

By the use of the "ALLENBURYS" DIET all trouble of peptonising -milk and farinaceous foods is overcome. In the sick room it will be found extremely useful as the food is easily digested and assimilated, is quickly made, and only the exact quantity required need be prepared at a time.

The "ALLENBURYS" DIET is made from pure, rich milk and whole wheat, both ingredients being partially predigested during manufacture. It can be taken by those who cannot digest cow's milk, and provides a light and very nourishing diet for Invalids, Dyspeptics and the Aged.

For travellers by sea or land this complete food will be found exceedingly valuable.

Made in a minute. Add boiling water only.

\section{A Sample with full particulare sent free on requeet. \\ ALLEN \& HANBURYS Ltd, 37 Lombard Street, London, E.C.}


JOURNAL OF MENTAL SCIENCE, OCTOBER, I9I3. iii

\section{SOUTH BEACON, \\ HADLOW DOWN, BUXTED, SUSSEX. ESTABLISHED 1892.}

Telegrams: "Hadlow Down." Stations: Buxted, Mayfield or Heathfield.

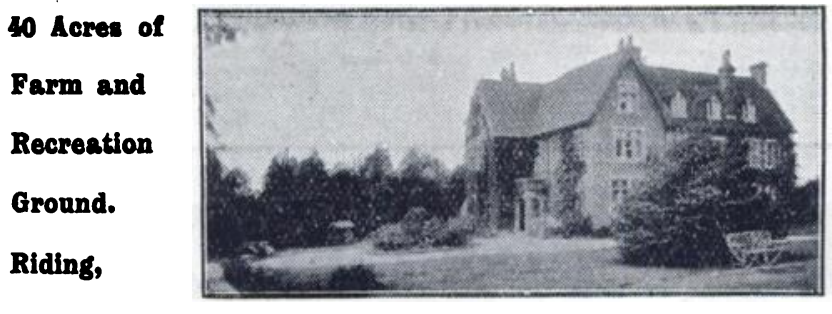

Drixing,

Hotoring,

Golf

and all

Outdoor

recreations.

For the Treatment of Nervous or slight Mental Breakdown.

TERMS FROM 3 GUINEAS PER WEEK.
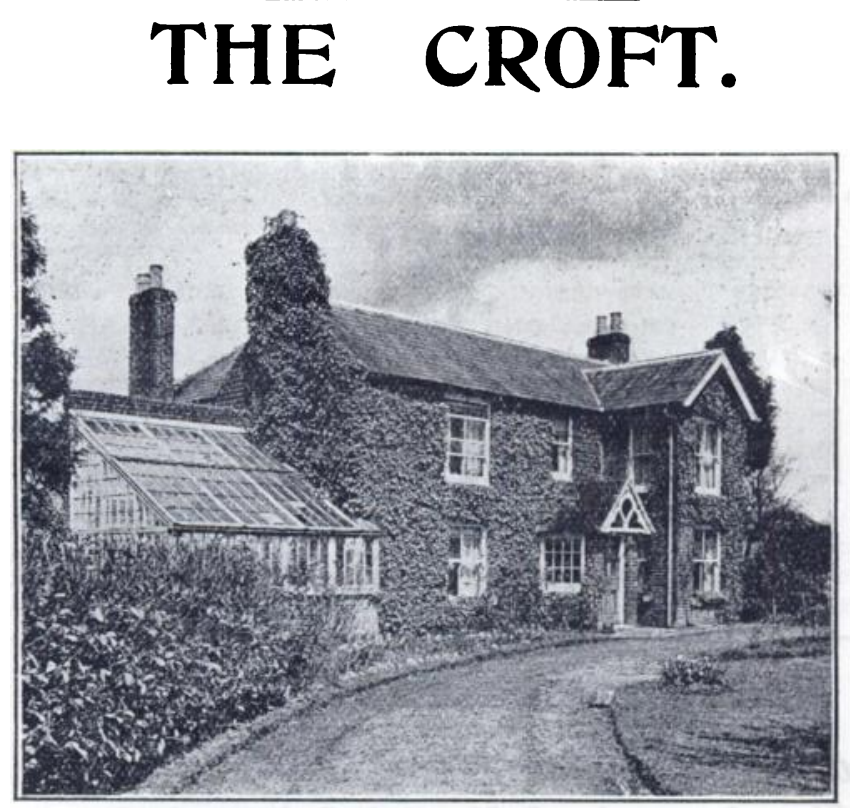

A comfortable cottage residence, where one gentleman can have special care and attention without necessarily coming into contact with other patients.

If desirable he can enjoy all the recreations provided at South Beacon-Motoring, Riding, Golf. 
iv JOURNAL OF MENTAL SCIENCE, OCTOBER, I9I3.
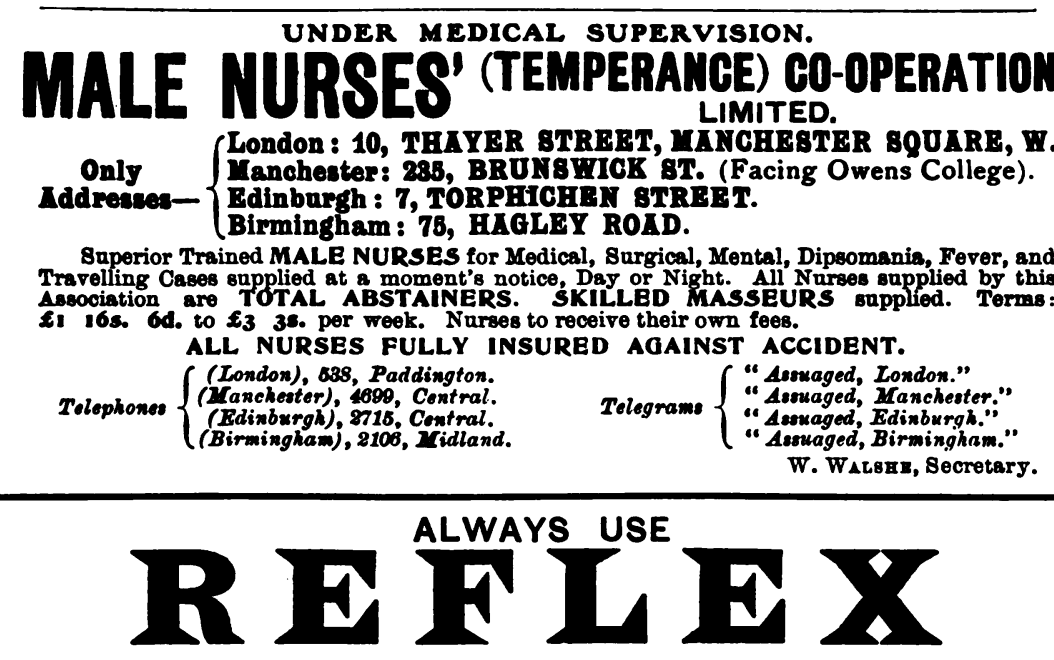

FLOOR POLISH.

REQUIRES NO MIXING WHATEVER.

Brilliantly Polishes Floors, Linoleums, Floorcloths, \&c.

Economical, Cleanly, Healthful; Maximum of Lustre for Minimum of Labour.

GEO. T. COX \& SONS, Ltd.,

9 \& 10, ST. MART-AT-HILL, EASTCHEAP, LONDON, E.C.

This Polish is specially adapted for use in Pablic Institutions and other large establishments. Samples Free on application.

\title{
BARNSLEY HALL, Meatat Preronte Pattents \\ - BROMSGROVE. - $\quad \begin{aligned} & \text { are received in connection with } \\ & \text { the Worcestershire Asylum. }\end{aligned}$ \\ EXTENSIVE PRIVATE GROUNDS IN THE BEAUTIFUL LICKEY DISTRICT. \\ Charge: ONE GUINEA WEEKLY. \\ For further particulars and necessary forms apply to the MEDICAL SUPERINTENDENT.
}

\section{THE RETREAT YORK TRAMED WUNSES \\ THE RETREAT, YORK. DEPARTMETT.}

Staffed by Nurses who have been trained for four years in the Retreat and conducted upon a profit-sharing basis. Mental and Nervous cases only undertaken. Terms 2 guineas weekly. Hale Nurses 22100.

Apply, IATROA, Retreat, York.

Mat. Tel. 112.

\section{NOTIOE TO ADVERTISERS.}

\author{
All Oommunioations oonoerning Advertlsements \\ In 'The Joumal of Mental Solonoe" should bo \\ addrosed to \\ MOssms. ADLARD \& SON, \\ Bartholomow Olose, Lomdon, E.O.
}

Telephone: Holborn 927. 


\section{JOURNAL OF MENTAL SCIENCE.}

\section{CONTENTS FOR OCTOBER, 1913.}

\section{Original Articles.-}

The Presidential Address, on the Prevention of the Insanities; by James Chambers, M.D.-Traumatic Neurasthenia; by H. Campbell Thomson, M.D., F.R.C.P.-The Bacteriological Examination of the Urine in some Cases of General Paralysis; by E. Barton White, M.R.C.S., L.R.C.P.Iond.Dysentery, Past and Present; by H. S. Gettings, L.R.C.P., D.P.H.-On the Bacteriology of Asylum Dysentery in England; by D. McKinley Reid, M.B., Ch.B.-The Róle of Syphilis in Mental Deficiency and Epilepsy: A Review of 205 Cases; by Kate Fraser, M.B., Ch.B., B.Sc., D.P.H., and H. Ferguson Watson, M.B., Ch.B., L.R.C.P.

\section{Oecasional Notes.}

The Annual Meeting of the Medico-Psychological Association.-International Medical Congress of 1913 .

\section{Reviews.-}

An Attempt to Expound the Psycho-analytical Theory.-Psychanalysis :

its Theory and Practical Application.

\section{Epitome of Current Literature.-}

1. Physiological Psychology.-2. Clinical Psychiatry and Neurology.-

3. Treatment of Insanity

\section{Notes and News.-}

The Medico-Psychological Association of Great Britain and Ireland.The Dinner.-International Congress of Neurology and Psychiatry.British Medical Association-Annual Meeting at Brighton, July, 1913Neurological and Psychological Sections.-Internationale Zeitschrift für Aerztliche Psycho-Analyse.-The Library of the Medico-Psychological Association.-Notices by the Registrar.-Notices of Meetings.-Recent Appointments . 